\author{
Małgorzata Rejter \\ https://orcid.org/0000-0003-1431-2163 \\ Uniwersytet Łódzki \\ Wydział Nauk Geograficznych \\ Instytut Geografii Miast, Turyzmu i Geoinformacji \\ Studium Doktorskie \\ UL0166122@edu.uni.lodz.pl
}

\title{
SPOŁECZNE DOŚWIADCZANIE MIASTA NA PRZYKŁADZIE ŁODZI - BIOGRAFIE Z LAT DZIECIŃSTWA I MŁODOŚCI
}

\begin{abstract}
Abstrakt: Celem artykułu jest zobrazowanie różnych aspektów życia społecznego w przestrzeni powojennej Łodzi przy wykorzystaniu metody biograficznej (9 wywiadów biograficznych/osobistych narracji). Praca stanowi studium relacji społecznych uwzględniających punkt widzenia indywidualnego narratora, który pozwala przenieść się w minione lata, poznać wygląd miasta oraz sposoby spędzania czasu przez jego mieszkańców. Uzyskane wyniki pokazują różnorodny przebieg życia i różne warunki mieszkaniowe oraz codzienne czynności, jakimi zajmowali się w okresie swojego dzieciństwa i młodości badani mieszkańcy Łodzi.
\end{abstract}

Słowa kluczowe: miasto, przestrzeń miejska, społeczność miejska, biografie.

\section{SOCIAL EXPERIENCE OF THE CITY USING BIOGRAPHIES FROM CHILDHOOD AND YOUTH: THE EXAMPLE OF ŁÓDŹ}

Abstract: The aim of the article is to present various aspects of social life in the space of the post-war city of Łódź, using the biographical method (9 biographical interviews/personal narratives) and it is a study of social relations. The role of these interviews is of significant value in the study, because from the narrator's individual point of view, we can move back to the past years, get to know the appearance of the city and ways of spending time by its inhabitants. The results were shown a diverse life course and differ living conditions as well as the daily activities of the inhabitants of Łódź dealt with in their childhood and youth.

Keywords: city, urban space, urban community, biographies.

\section{WPROWADZENIE}

Miasto jest dziełem, mającym swoją historię oraz społeczność, która utożsamia się z tym miastem, kreuje je według własnych potrzeb, upodobań i możliwości (Miszewska, 2014). Stanowi konstrukcję przestrzenna, jednak ma rozległą rozpiętość, którą możemy rozpatrywać w różnych przedziałach czasowych. Patrząc z punktu widzenia różnych osób i z różnych perspektyw, takie sekwencje czasowe są w mieście przerywane i zakłócane. W każdym miejscu i czasie dzieje się więcej, niż możemy zaobserwować, a wydarzenia te czekają na uważnego obserwatora, który je podda wnikliwej analizie. Żadne zdarzenie nie zachodzi w izolacji, każde działanie wchodzi w relację z otoczeniem. Równie ważne są sekwencje poprzedzające konkretne wydarzenia i pamięć o wcześniejszych doświadczeniach (Lynch, 2011). Dlatego też tak ważna jest możliwość poznania tego, jak kiedyś żyli ludzie, co dla nich było istotne i warte zapamiętania po wielu dekadach życia. Jest to możliwe dzięki osobom, które zechciały opowiedzieć historię swojego życia.

\section{PRZEGLĄD LITERATURY}

W artykule przedstawiono spojrzenie na miasto oczyma jego mieszkańców. Głównym kierunkiem zainteresowań autorki zaprezentowanym w pracy jest społeczne widzenie Łodzi w II połowie XX w. Miasto, szczególnie tak duże jak Łódź, można badać z różnych punktów widzenia i pod wieloma względami. Jednak najczęściej patrzy się na nie, jak na złożony organizm społeczny i gospodarczy, który determinuje rozwój ekonomiczny. W artykule analizie poddane zostały społeczne aspekty przestrzeni miasta. 
Opisanie fragmentu miasta, to sposób widzenia miejskiego środowiska. Jest to również propozycja wyobrażenia sobie miasta jako układu zredukowanego do wymiaru społeczno-przestrzennego, którego rozmiar umożliwia poznanie go przez poszczególne jednostki. Poznanie to ograniczane jest poprzez empirię i zasięg osobistych kontaktów społecznych. Wymiar społeczny identyfikuje tę część zbiorowości, która zajmuje wraz z podmiotem wspólną przestrzeń i oddziałuje na siebie, a takim przykładem może być grupa sąsiedzka lub rówieśnicza. Obszar terytorialny wyznacza przestrzeń, w której zachodzą doświadczenia i możliwości poznawcze. Granice, wyodrębnionych z przestrzeni miasta i zbiorowości ludzkiej, fragmentów wyznaczają właściwe każdemu człowiekowi cechy zależne od jego wieku, pochodzenia, pozycji, ról społecznych, aktywności, przynależności, relacji utrzymywanych z innymi, lokalizacji i jakości miejsca zamieszkania. Cechy te zmieniają się z upływem czasu w następstwie wydarzeń w biografii, ale dla dzieci ich mały świat stanowi ograniczoną przestrzeń w grupie pierwotnej, podstawowej, uniwersalnej dla wszystkich społeczności, pełni rolę małej zbiorowość, do której należą, takiej jak rodzina, grupa sąsiedzka i rówieśnicza (Majer, 2015).

Łódź wyróżnia się specyficzną genezą i fazami rozwoju. Na potrzeby pracy przeanalizowano przemiany miasta w II połowie XX w., ze względu na przypadający na ten czas etap dzieciństwa i młodości osób uczestniczących w badaniach. W pierwszej dekadzie po wojnie w Łodzi odnotowano wysoki przyrost naturalny, zwiększyła się również liczba przybywających do miasta migrantów. Zjawiska te rekompensowały straty ludności z okresu II wojny światowej, które wynikały z zagłady ludności żydowskiej, eksterminacyjnej polityki wobec polskich mieszkańców miasta, przymusowych wyjazdów łodzian i deportacji ludności o niemieckich korzeniach. Po zakończeniu II wojny światowej granice administracyjne Łodzi zostały wyznaczone na podstawie Rozporządzenia Rady Ministrów z dnia 20.12.1945 roku. W konsekwencji obszar miasta powiększył się o $152,7 \mathrm{~km}^{2}$, osiągając $211,5 \mathrm{~km}^{2}$ - przed wojną Łódź miała jedynie $58,8 \mathrm{~km}^{2}$ powierzchni. Do miasta przyłączono 90 okolicznych wsi, osiedli i osad graniczących z Łodzią. Miasto podzielono na 7 dzielnic (Staromiejska, Ruda, Śródmieście, Bałuty, Widzew, Górna i Polesie), jednak taki układ administracyjny utrudniał prowadzenie jednolitej polityki miejskiej. Zatem w $1960 \mathrm{r}$. zmniejszono liczbę łódzkich dzielnic do 5 (Śródmieście, Bałuty, Widzew, Górna i Polesie) (Lesiakowski, 2019) i taki podział dzielnicowy funkcjonuje do dziś.

W 1946 r. w Łodzi znajdowało się 149314 mieszkań, rozmieszczonych na powierzchni 21155 ha. W porównaniu do 1939 r. było to 51,6 tys. mieszkań mniej. Powodem ubytku substancji mieszkaniowej były zniszczenia w okresie wojny i okupacji, wycofanie z użytkowania zabudowań grożących zawaleniem i przeznaczenie budynków mieszkalnych na szkoły, siedziby władz, urzędów i instytucji o charakterze publicznym (Kaczmarek, 1996).

Łódź po II wojnie światowej liczyła niespełna 500 tys. mieszkańców. Przez krótki czas była największym miastem w Polsce, a ze względu na zniszczenie Warszawy przejęła część funkcji stołecznych. W latach 1975-1998, w związku z reformą podziału administracyjnego, powstało województwo łódzkie (najmniejsze województwo w Polsce), które obejmowało Łódź i okoliczne miejscowości. W 1988 r. do Łodzi przyłączono kolejne wsie, zwiększając tym samym powierzchnię miasta o $80 \mathrm{~km}^{2}$ (Kwiatek, Lijewski, 1998).

W pierwszych latach powojennych w Łodzi, posiadając niewielkie fundusze, zmierzano jedynie do przebudowy zrujnowanych budynków mieszkalnych, zatem przyrost liczby izb, przypadający na nowe budownictwo, był niewielki. Następnie rozpoczęto realizacje programu budowy współczesnych osiedli mieszkaniowych, który opracowany został w Biurze Programowania i Projektowania Rozwoju Łodzi. W latach 1946-1949 oddano do użytku mieszkańców 2,6 tys. izb mieszkalnych. Szybki przyrost naturalny ludności powodował wzrost zagęszczenia mieszkań. Następowały znaczne ubytki izb głównie w starych budynkach drewnianych. Charakterystyczną cechą łódzkiego budownictwa mieszkaniowego w tych latach była tendencja zmniejszania liczby izb w mieszkaniach. Wywoływało to ujemne skutki przy dominującym udziale rodzin wieloosobowych. Wskaźnik wielkości mieszkań oddanych do użytku, wyrażony liczbą izb, które przypadały na jedno mieszkanie, wynosił 2,2 i był najniższy w dwudziestoleciu 1945-1965. W związku z przewagą małych mieszkań w budownictwie starano się dążyć do zaspokajania narastających potrzeb mieszkaniowych. Jednak poprawa sytuacji lokalowej była możliwa tylko dla niewielkiej grupy ludności, o czym świadczą duże wartości liczb małżeństw przypadających na tysiąc nowych mieszkań i niskie wartości liczb nowych izb i mieszkań w przeliczeniu na tysiąc mieszkańców. Istotne zmiany w polityce mieszkaniowej nastąpiły w okresie planu sześcioletniego w latach 1950-1955, kiedy Łódź uzyskała 28,2 tys. nowych izb, w 8 tys. mieszkań. W połowie lat 60 . XX w. przyspieszono tempo uspołecznionego budownictwa mieszkaniowego, co wymagało zastosowania nowych rozwiązań technicznych, konstrukcyjnych i nietradycyjnych materiałów budowlanych oraz opracowania nowoczesnych technologii. Wszystko to miało swoje odzwierciedlenie w wyglądzie i walorach użytkowych domów. W większości budynki te były domami wielorodzinnymi, miały trzy klatki schodowe i pięć kondygnacji. Zostały wzniesione metodą wielkopłytową i były 
wyposażone w urządzenia sanitarno-techniczne. Natomiast $\mathrm{w}$ budownictwie prywatnym dominowały domy jednorodzinne, mające jedno mieszkanie $\mathrm{z}$ czterema izbami, budowane z cegły lub pustaków, pozbawione przyłączeń do urządzeń sieciowych (Dzieciuchowicz, 1974). Nawet jeśli rozwój terytorialny Łodzi (oraz powstawanie nowych osiedli mieszkaniowych) następował w wolnym tempie, to i tak stawał się przyczynkiem do intensyfikacji migracji wewnętrznej mieszkańców miasta w poszukiwaniu lepszego miejsca zamieszkania (Kaczmarek, Liszewski, 1991). Program przyspieszonego budownictwa mieszkaniowego, który stał się możliwy dopiero dzięki wznoszeniu mieszkań ze środków publicznych, był odpowiedzią na potrzeby społeczne Łodzi, jak i innych polskich miast oraz miast $w$ innych krajach. Z podobnymi problemami borykano się również m.in. we Francji, głównie w Paryżu (Castells, 1982).

Badania nad mieszkalnictwem określane są jako studia mieszkaniowe, które prowadzi się na gruncie wielu nauk. Interdyscyplinarny charakter tych badań sprawia, że są one w kręgu zainteresowań geografów, socjologów, ekonomistów, historyków, antropologów społecznych, urbanistów, architektów, planistów, psychologów środowiskowych, badaczy nauk prawnych i politycznych. Najważniejsze obszary badawcze w studiach mieszkaniowych to opis i analiza polityki mieszkaniowej, badania aspektów ekonomicznych mieszkalnictwa oraz analiza geograficzna, która zmierza do wyjaśniania powodów wpływających na przestrzenną dystrybucję mieszkań. Ponadto analiza geograficzna wykorzystywana jest do badania decyzji mieszkaniowych gospodarstw domowych i przebiegu ruchliwości przestrzennej oraz analizowania nierówności w dostępie do zasobów mieszkaniowych. Nie mniej ważny aspekt $w$ studiach mieszkaniowych stanowi dziedzina badań związana z doświadczaniem, odkrywaniem sensu i znaczenia domu, mieszkania, określana geografią domu (Szafrańska, 2016).

Widzenie i przeżywanie miasta w wymiarach odpowiadających percepcji jednostek, w skali osobistej, czyli mikro, to mikropolis. Innymi słowy jest to fragment miasta uznawany za swój, tworzący oswojoną część, w której mieszkańcy są rodzina, przyjaciółmi, znajomymi bliższymi lub tylko z widzenia, sąsiadami bliskimi i dalszymi. Mikropolis jest to część miasta stanowiąca swoje osobiste miasto w mieście. Człowiek w swojej naturze ma potrzebę zakorzenienia się w określonym miejscu. Dzięki temu może budować własną tożsamość, poczucie przynależności i bezpieczeństwa. Daje mu to satysfakcję bycia skądś i świadomość posiadania własnego miejsca na Ziemi. Dzięki temu co bliskie i znajome utrzymuje wewnętrzną równowagę i zachowanie regularnego rytmu dnia. Aby osiągnąć udane życie potrzebujemy przywiązania do ludzi i miejsca, w którym panują swojskie stosunki społeczne, generowane przez wspólny język, zwyczaje, styl życia. Takie przywiązanie rzutuje na oddanie dla miasta czy kraju, a wyznacznikiem tego przywiązania jest mieszkanie lub dom, ulica bądź mniejszy czy większy fragment miasta (Majer, 2015). Ponadto każde miasto jest przestrzenią zorganizowana, nasyconą wielorakimi sensami i określonymi miejscami (Żyłko, 2000). W przestrzeni miasta zapisane są wszystkie elementy świadczące o jego przeszłości (Miszewska, 2014). Możemy je odkryć dzięki historiom opowiedzianym przez mieszkańców miasta. Szczególnie ciekawe są opowieści z okresu powojennego, gdyż miejsca życia ich bohaterów przykryte zostały już kolejnymi warstwami palimpsestów i dla współcześnie patrzących na miasto są niewidoczne, a pozostają jedynie w pamięci dawnych mieszkańców. Takie miejsca obrazują relacje, jakie zachodziły i zachodzą pomiędzy człowiekiem a środowiskiem, są fragmentem przestrzeni o symbolicznym znaczeniu, stanowiąc rezultat indywidualnych doświadczeń człowieka, tworzą część przestrzeni społecznej intensywnie nasyconą uczuciami i myślami. Miejsca jednostkowe są to obszary związane z życiem konkretnych osób, które potrafią je opisać i są niedostępne dla postronnego obserwatora. Możliwość poznawania takich miejsc wynika z przebiegu życia jednostek, dlatego nie można ich badać w sposób całkowicie zobiektywizowany, ponieważ są one dostępne tylko konkretnym osobom w trakcie ich życia (Kaczmarek, 2001). Miasto jest przede wszystkim środowiskiem życia człowieka, który jest jednocześnie twórcą miasta, jego użytkownikiem i najważniejszym elementem. Poza tym miasto jest zgrupowaniem budynków i koncentracją usług (Zieliński, 2014). Wszystko to razem tworzy charakterystyczny krajobraz miejski, specyficzny i unikatowy dla każdego okresu historycznego.

Materiał do artykułu zebrano dzięki wykorzystaniu metody biograficznego wywiadu narracyjnego. W wymiarach indywidualnej biografii jej przebieg i trwanie ujawniają się w sekwencji struktur procesowych. Pozwala to porównywać jednostkowe losy biograficzne i badać zarówno swoiste formy przebiegu ludzkiego życia, jak i ich zaangażowanie w procesy społeczne. Wybór takiej metody jest badaniem niezwykłości przebiegu życia ludzkiego, a jednocześnie fenomenu społecznego przez pryzmat biografii. Sama narracja daje możliwość poznania światów i procesów społecznych związanych z przebiegiem życia (Kaźmierska, Waniek, 2020).

Najważniejszym zadaniem stawianym $\mathrm{w}$ artykule jest wyznaczenie wyjątkowego miejsca narratorów, stanowiącego indywidualna, niepowtarzalną przestrzeń dla każdego człowieka w świecie. Dlatego też najistotniejszą częścią pracy jest egzystencjalny opis życia narratorów opowiedziany przez nich samych. Dzięki temu poznajemy role społeczne, jakie odgrywali w swoim życiu i możemy dostrzec obrazy wyjątkowości kulturowego wymiaru ich istnienia (Darmach, 2020). 


\section{ZASTOSOWANA METODA BADAWCZA}

Metodologia artykułu opiera się na konwencji socjologii codzienności, tzw. trzeciej socjologii. Badacze pierwszej socjologii zajmują się zgeneralizowaną społecznościa, drugiej działaniami społecznymi i interakcjami, a trzeciej skupiają się na analizach sieci wielokierunkowych relacji między jednostkami. Sieci stanowią jednostkowo-społeczne pola, które są nieustannie zmienne, płynne i znajdują się w procesie ciągłego powstawania zdarzeń społecznych, działań ludzi wobec siebie, w powiązaniu $\mathrm{z}$ innymi w ramach wspólnoty wykorzystywanej dla wspólnych działań (Majer, 2015). W artykule mamy zatem do czynienia z połączeniem koncepcji socjologii codzienności oraz idei geografii społecznej. Metodą wybraną do badań są biograficzne wywiady narracyjne (z istotnymi kontekstami terytorialnymi), które przeprowadzono w latach 2017-2020 z siedemnastoma mieszkańcami Łodzi, a dziewięć narracji poddano analizie w niniejszym artykule. Osoby opowiadające nazwano „narratorami", są to łodzianie w wieku senioralnym z biologicznego punktu widzenia, czyli osoby powyżej 65 roku życia. Dobór próby do badań był celowy, a autorka dążyła do uzyskania od badanych historii ich codziennego życia w mieście. Aby zrealizować cel badawczy wybrano technikę wywiadu, ponieważ „wywiad przeprowadza się w przypadku, gdy nie ma możliwości uzyskania informacji lub ustalenia faktów o danej populacji (zbiorowości) innymi technikami badań. Polega on na pozyskiwaniu danych przy pomocy bezpośredniej rozmowy" (Apanowicz, 2002, s. 83).

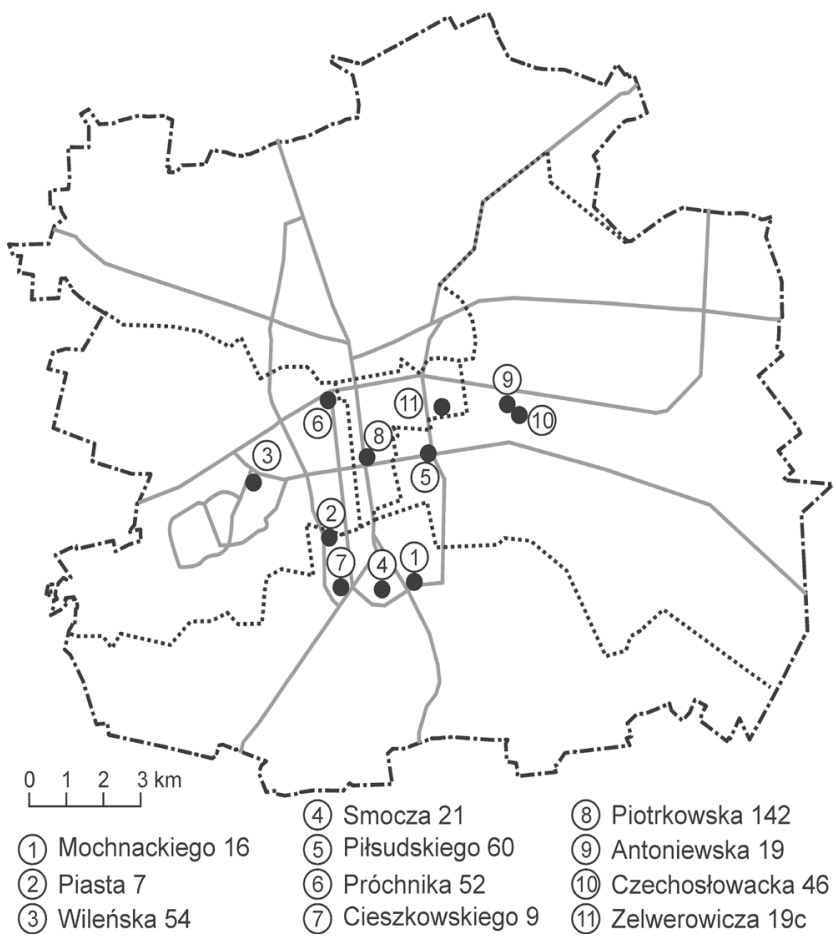

Rysunek 1. Miejsca zamieszkania narratorów Źródło: opracowanie własne
Analizie poddano okres przypadający na lata powojenne, czyli czas dzieciństwa i młodości narratorów. Kolejne miejsca zamieszkania narratorów (w sumie jedenaście) naniesiono na mapę $\mathrm{w}$ celu pokazania ich rozmieszczenia w przestrzeni Łodzi (rys. 1). Po każdym wywiadzie w tekście umieszczono fotografie omawianych miejsc.

Z przedstawianych biografii wyłania się obraz powojennej Łodzi, opis warunków mieszkaniowych oraz aktywności jakimi zajmowali się narratorzy. Warunki mieszkaniowe, w jakich żyli różnią się między sobą dość znacznie. $Z$ punktu widzenia fenomenologicznego zaprezentowane biografie pokazują życie codzienne i jego subiektywne doświadczanie przez narratorów. Świat codziennego życia został pokazany w strukturze przestrzennej (Łódź, miejsce zamieszkania i pobliskie okolice), czasowej (II połowa XX w.) i społecznej (rodzina, sąsiedzi, znajomi, koledzy). Darmach (2020) przyjmuje, że fenomenologia jest nauką o istocie rzeczy, która osadza się w egzystencji i w istnieniu, a człowieka można zrozumieć dzięki faktyczności.

\section{SPOŁECZNE WIDZENIE ŁODZI OCZAMI JEJ MIESZKAŃCÓW}

WYWIAD 1 (2.09.2017)

\begin{abstract}
Nazywam się S., urodziłam się 2 października 1941 r. w Łodzi i przez całe życie mieszkałam w Łodzi. Pierwszym moim miejscem zamieszkania był budynek drewniany wielorodzinny przy ul. Mochnackiego 16. Mieszkałam tam wraz ze swoimi rodzicami, moim starszym bratem W. i dziadkami, rodzicami mojej matki $\mathrm{w}$ jednym pokoju z kuchnią. Pamiętam, że budynek miał piwnicę, $\mathrm{w}$ której się chowaliśmy podczas nalotów w czasie wojny. Potem po wyjściu z domu widziałam zbombardowane budynki. Pamiętam również, że mimo wojny chodziłam ze starszym bratem W. i jego kolegą Z. do pobliskiego kina.
\end{abstract}

Dzieciństwo narratorki przypada na lata 40. XX w., urodziła się ona jako drugie dziecko $w$ trzypokoleniowej rodzinie. Mieszkała wraz z rodziną w jednym pokoju z kuchnia, bez żadnych wygód, w drewnianym budynku przy ulicy Mochnackiego 16. Budynek ten nie przetrwał do czasów obecnych, a w jego miejscu znajduje się teraz trawnik i chodnik dla pieszych (fot.1). Można przypuszczać, że nieistniejący już drewniany budynek wyglądał podobnie jak ten znajdujący się przy ulicy Marynarskiej 54, który pozostaje w zasobach Administracji Nieruchomościami Łódź „Bałuty Stare II" (fot. 2). Budynek przeznaczony jest do wyburzenia, także już niedługo i jego nie zobaczy się w tkance miasta.

W przestrzeni Łodzi pozostało już niewiele drewnianych domów. Niegdyś dominujący typ zabudowy, 
od XIX w. stopniowo wypierany przez coraz to wyższe murowane budynki. W okresie międzywojennym drewniaki stanowiły $28 \%$ ogółu zabudowy w Łodzi. Wiele $\mathrm{z}$ nich wyburzono $\mathrm{w}$ trakcie II wojny światowej oraz w latach 70 . Z zabytkowych domów tkaczy, stojących wzdłuż południowego odcinka Piotrkowskiej, dzisiaj możemy zobaczyć jedynie pojedyncze przykłady

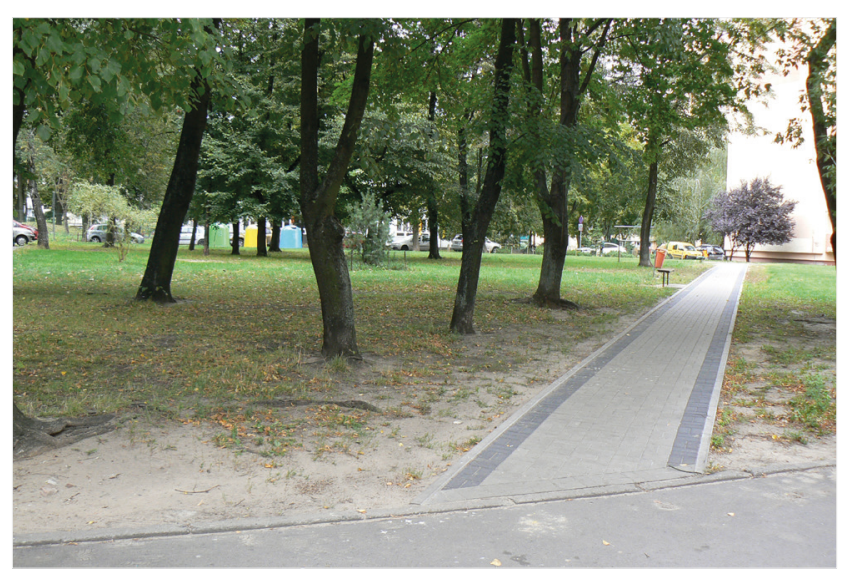

Fotografia 1. Ulica Mochnackiego 16 Źródło: M. Rejter (2020)

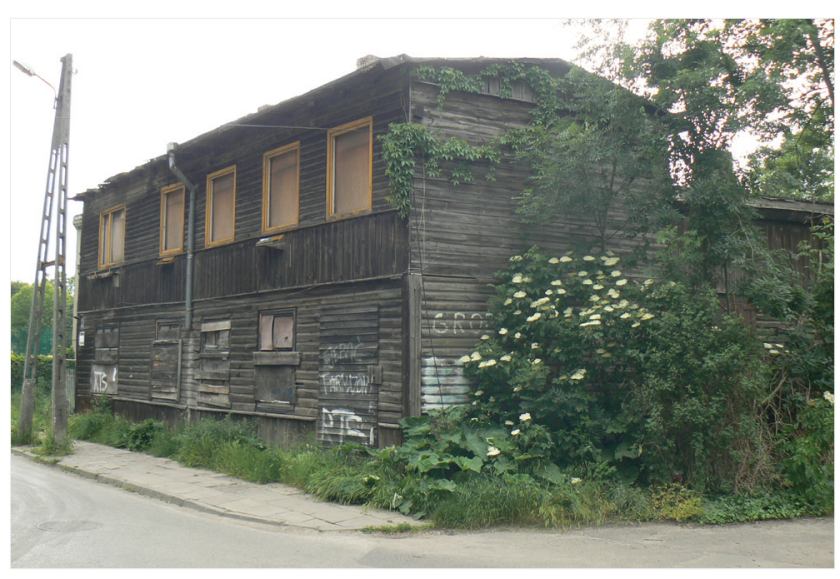

Fotografia 2. Ulica Marynarska 54 Źródło: M. Rejter (2020)

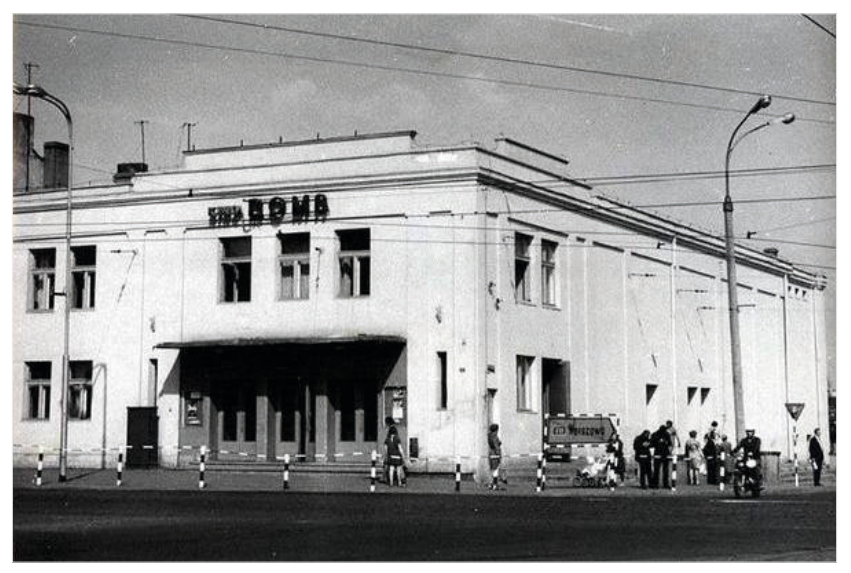

Fotografia 3. Kino „Roma” Źródło: Baedeker łódzki (2015) w centrum miasta. Stosunkowo dużo takich budynków zachowało się na dawnych przedmieściach, takich jak Bałuty (fot. 2), Chojny, Marysin czy Złotno, chociaż i tam znikają w szybkim tempie, ustępując miejsca nowej zabudowie mieszkaniowej (Nykiel, 2020).

Narratorka wspomina miłe chwile spędzane z bratem, takie jak wizyty w kinie. „Dawniej kina niemal zawsze były wypełnione po brzegi, bilety kosztowały grosze, a atmosfery nie sposób zapomnieć nawet po tych kilkudziesięciu latach" (Czechowicz, 2015). Narratorka chodziła do kina „Roma”, które działało przy ulicy Rzgowskiej 84 (fot. 3). Były to zdarzenia na tyle istotne w biografii narratorki, że nadal pozostały w jej pamięci, mimo iż była wtedy dzieckiem. Budynek kina "Roma" istnieje do tej pory, zmienił jedynie funkcję użytkową.

\section{WYWIAD 2 (15.02.2018)}

Nazywam się K., urodziłam się 28.05.1941 r. w Łodzi na ulicy Piasta 7, mieszkałam w takiej wielkiej kamienicy, która istnieje do tej pory. [...] mam nawet takie zdjęcie, jak stoję w ogrodzie (fot. 4), który był po drugiej stronie ulicy Piasta 7, gdzie stoi teraz tam elektrociepłownia. To tam był ogród z pięknym stawem, gdzie były raki. Pamiętam, że tam chłopaki łapali te raki, czyli musiała być czysta woda i mogliśmy się tam też kąpać. Tam było takie małżeństwo, u których się kupowało kwiaty i warzywa. Pamiętam, że tam było ślicznie, no ale jak zaczęli budować elektrociepłownię to skasowali ten park.

Dzieciństwo narratorki przypada na lata 40. XX w., mieszkała ona w kamienicy przy ulicy Piasta 7 (fot. 4), po przeciwnej stronie ulicy znajdował się duży ogród, który narratorka wspomina z nostalgią i rozrzewnieniem, ponieważ to $\mathrm{w}$ nim, wspólnie $\mathrm{z}$ innymi dziećmi z okolicy, mogła spędzać czas (fot. 5). Z żalem wspomina, że w 1955 r., kiedy to rozpoczęła się budowa elektrociepłowni EC-2, teren ogrodu został zaanektowany

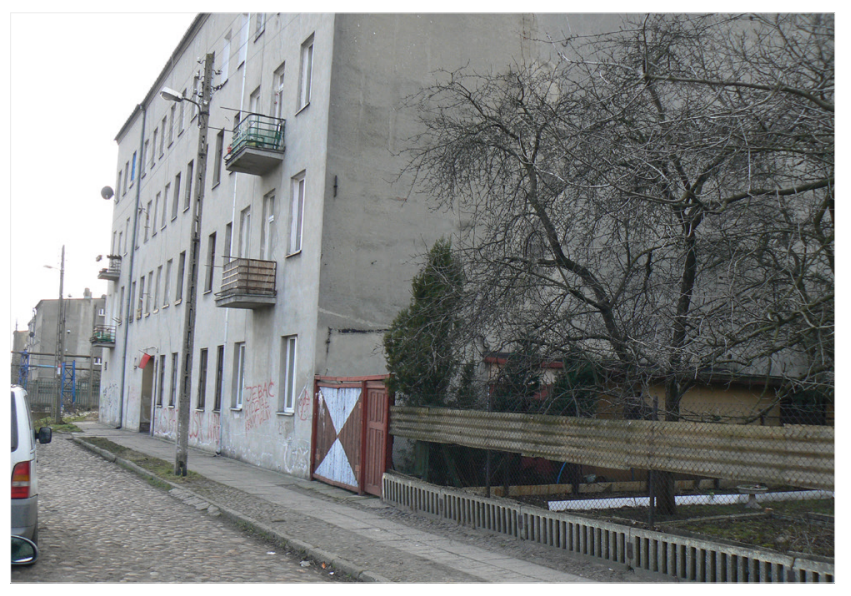

Fotografia 4. Ulica Piasta 7

Źródło: archiwum narratorki 


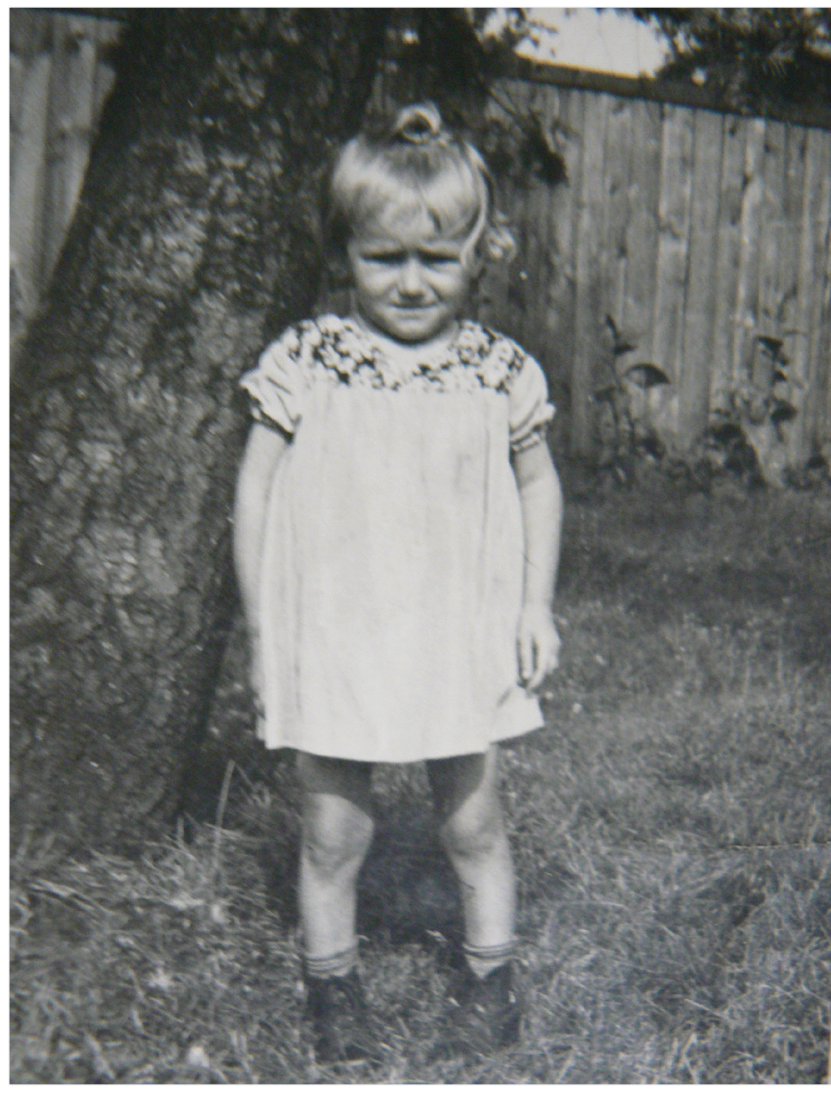

Fotografia 5. Dziecko w ogrodzie (1945)

Źródło: archiwum narratorki

pod budynki elektrociepłowni. Narratorka miała wtedy 14 lat. Było to ważne wydarzenie w jej życiu, gdyż w okresie dzieciństwa ogród ten spełniał rolę placu zabaw, miejsca wypoczynku i rekreacji, a co ważne można tam też było kupować świeże warzywa, owoce i kwiaty od właścicieli tego terenu. Wszystkie te korzyści zniknęły po przeznaczeniu tego obszaru pod elektrociepłownię, która miała służyć mieszkańcom - rodzinie narratorki niestety nie przysłużyła się, gdyż kamienica, w której mieszkali, nie została podłączona pod centralne ogrzewanie. Zatem osobiście narratorka, jak również inne dzieci z okolicy, straciła na tej budowie fragment przestrzeni, w której spędzała czas wolny, pozostała jedynie pustka i nostalgiczne wspomnienia za utraconym miejscem dziecięcych zabaw.

\section{WYWIAD 3 (16.08.2018)}

Nazywam się J., urodziłam się 19 kwietnia 1942 r., w miejscowości Barłogi. Urodziłam się na wysiedleniu, ponieważ moi rodzice zostali wysiedleni w czasie wojny z Łodzi, gdzieś na wieś w nieznanym kierunku. Moi rodzice do Łodzi przeprowadzili się z powrotem w 1945 r. Ich mieszkanie było zamieszkane przez innych ludzi, nie znaleźli swojego dobytku, nie znaleźli niczego, musieli dorabiać się od początku. Mieszkanie uzyskali, ponieważ brat mojego taty w Sieradzu wybudował domek, na osiedlu kolejarskim, i tam się wyprowadził. A tutaj, na ulicy Wileńskiej 54, zostawił moim rodzicom. I tak zaczęło się moje życie w Łodzi. W tej chwili tam stoją tylko bloki, ale w 1976 r. jeszcze ten budyneczek, mały drewniaczek stał. Drewniaczek z takim poddaszem, mieliśmy pokój z kuchnią. Dzierżawili moi rodzice ogródek poniemiecki, ponieważ dom był poniemiecki. [...] W 1952 r. wyprowadziłam się wraz z rodzicami na ulicę Smoczą 21, tam mieliśmy pokój z kuchnią. Był to budynek drewniaczek, mieszkanko miało w sumie 38 metrów, bez żadnych wygód, był tylko prąd, ubikacja w podwórku, woda na ulicy, na całe szczęście tuż przy bramie, taki uliczny hydrant. Chociaż zaraz, jak się tam sprowadziliśmy, to nie było wody. Po wodę jeździło się gdzieś na którąś ulicę dalej. A ścieki wylewało się do rynsztoka. Paliło się, gotowało na piecu, to była taka szamotówka, dwie fajerki, no jak się paliło, to było ciepło, a jak się nie paliło, to było zimno, to woda zamarzała. No, ale takie warunki były.

Dzieciństwo narratorki przypadło na lata 40. i 50. XX w. Pierwszym miejscem jej zamieszkania był drewniany domek przy ulicy Wileńskiej 54 , który pod koniec lat 70. XX w. został wyburzony, a na jego miejscu teraz są bloki mieszkalne (fot. 6). Drugim miejscem zamieszkania narratorki od 1952 r. był drewniany domek przy ulicy Smoczej 21 (fot. 7). Warunki mieszkaniowe w obu tych domkach, jak i w większości domów w tym okresie, były podobne: brak wody, kanalizacji, ogrzewania, toaleta w podwórzu oddalona od domu. Żaden z zamieszkiwanych przez narratorkę domów nie przetrwał do dzisiaj, jednak wspomnienia o nich i o warunkach zamieszkania są wciąż żywe w pamięci narratorki. Domy, w których mieszkała narratorka, nie istnieją a ich miejsce zajęły osiedla z wielkiej płyty, tak pospolite w Łodzi (fot. 6, fot. 7). Artykuł ma na celu przypomnieć, że kiedyś ludzie żyli inaczej, mieli inne problemy, ich życie rządziło się innymi prawami.

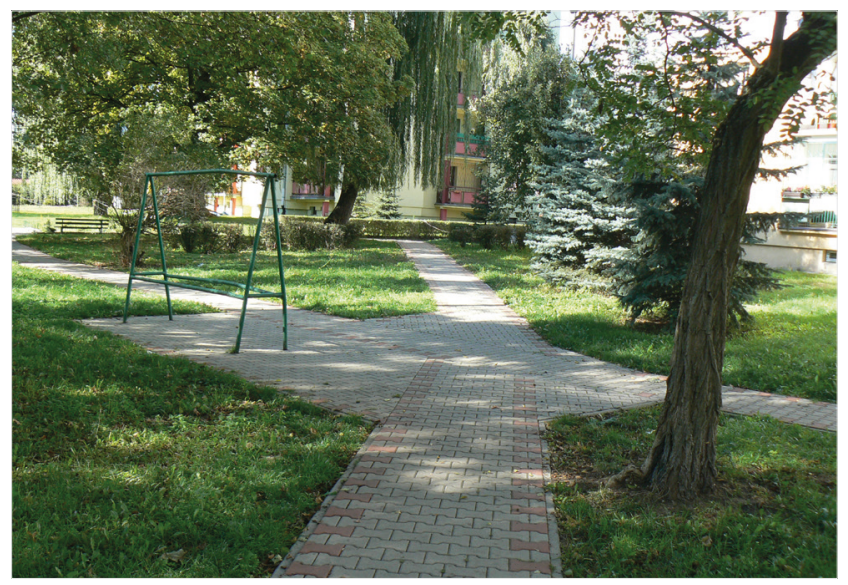

Fotografia 6. Ulica Wileńska 54 Źródło: M. Rejter (2020) 


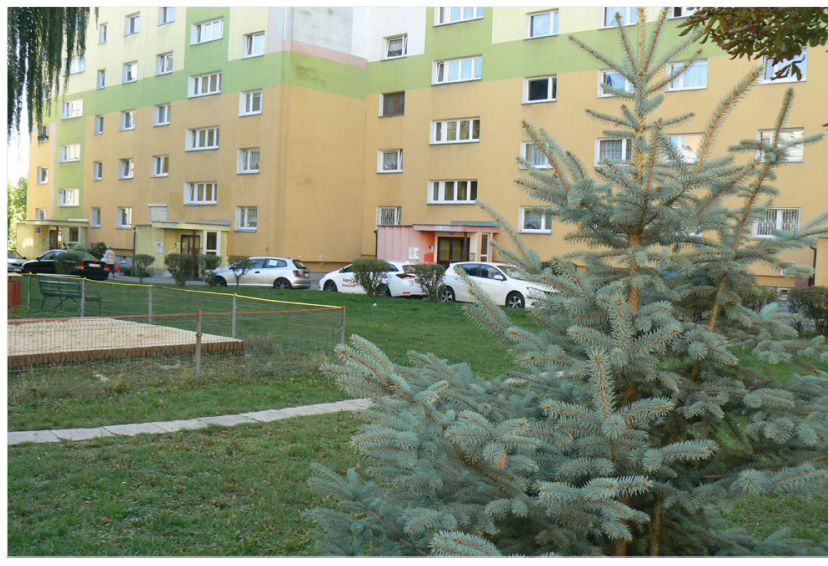

Fotografia 7. Ulica Smocza 21 Źródło: M. Rejter (2020)

Autorka pragnie pokazać, że współcześni mieszkańcy bloków zastąpili ówczesnych mieszkańców drewnianych domów, którzy potrafili znaleźć szczęście mimo skromnych warunków życia.

\section{WYWIAD 4 (19.05.2018)}

Nazywam się W., urodziłam się w 1942 r. na wsi, to jest w Gutkowicach Nowych w powiecie skierniewickim. I tam mieszkałam do siódmego roku życia. Przeprowadziłam się do Łodzi, znaczy się rodzice się przeprowadzili do Łodzi, i już do szkoły podstawowej chodziłam w Łodzi na ulicy Targowej. Pierwszy mój adres zamieszkania w Łodzi to była ulica Główna 60 . To była stara, duża kamienica pożydowska, tam był jeden duży pokój z kuchnia, około $32 \mathrm{~m}^{2}$, na pierwszym piętrze. Mieliśmy prąd i wodę w mieszkaniu, bo mój ojciec założył tę wodę, bo była tylko na korytarzu dla wszystkich lokatorów na piętrze. Lokatorów na piętrze było gdzieś pięciu czy sześciu i każdy miał po pokoju czy pokój z kuchnią. My jedni mieliśmy wodę i zlew w mieszkaniu, bo tak to była tylko na korytarzu. O łazience nie było mowy. Ubikacja to była na podwórku. Ogrzewane mieszkanie było przez piec szamotowy. Gotowało się na piecu, a latem tylko na maszynce elektrycznej, bo z pieca się strasznie kopciło. Ten dom był niski, a wszystkie inne były wysokie i bardzo się kopciło. W pokoju był taki piecyk przenośny. Mieszkałam tam w cztery osoby, razem z rodzicami i moją młodszą o trzy lata siostra, a potem z mężem, w 1960 r. wyszłam za mąż, i córkami aż do 1976 r., do wyburzenia całej ulicy Głównej. Trudne były warunki, bo tam trzeba się było myć w wanience takiej metalowej raz w tygodniu. [...] Na podwórku była toaleta murowana zamykana na klucz, kto z kim chciał to miał i trzeba było o nią dbać. Gdzie indziej były też komórki drewniane na węgiel.

Czasy dzieciństwa, które narratorka spędziła w Łodzi, przypadają na lata 50. XX w. Pierwszym miejscem zamieszkania narratorki w Łodzi była kamienica przy

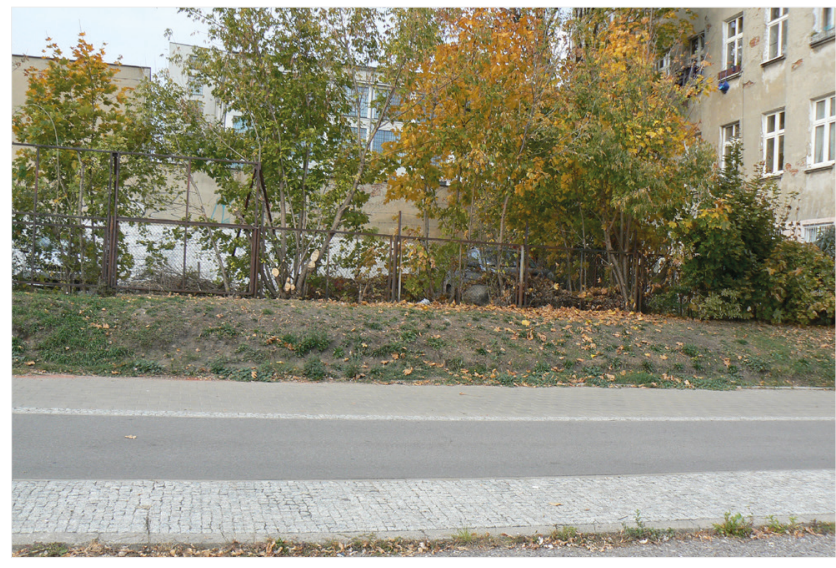

Fotografia 8. Aleja Piłsudskiego Zródło: M. Rejter (2020)

ulicy Głównej 60 (w 1990 r. przemianowana na Aleję Piłsudskiego). Kamienica ta, wraz z dwoma innymi, znajdowała się między ulicami Dowborczyków a Targową. Były to kamienice pod adresem Główna 58, Główna 60 i Główna 62 i budynki te, w latach 60. XX w., zostały przeznaczone do rozbiórki ze względu na rozbudowę ulicy Głównej, z ulicy jednojezdniowej na wielopasmową arterię szybkiego ruchu. Kamienica znajdująca się pod adresem Główna 62 nazywana była przez okolicznych mieszkańców „Palestyna” - ze względu na to, że zamieszkujący ją łodzianie byli w większości Żydami. Narratorka bardzo cieszyła się z powodu wyburzenia kamienicy, ponieważ już wcześniej planowała przeprowadzkę do bloków, lecz mimo wpłaty wkładu członkowskiego do Spółdzielni Mieszkaniowej czekała na mieszkanie już kilka lat, a wyburzenie kamienicy skutkowało przyspieszeniem otrzymania mieszkania w blokach. Ze względów finansowych nie wszyscy lokatorzy zamieszkujący kamienice byli zainteresowani przeprowadzką do bloków, otrzymali zatem w zastępstwie mieszkania $w$ innych kamienicach. Natomiast z kilkoma sąsiadami z kamienicy narratorka dostała przydział mieszkania w jednym bloku. Była $z$ tego powodu zadowolona, ponieważ mimo zmiany miejsca zamieszkania otoczenie sąsiedzkie pozostało jej znane i przyjacielskie. Z kilkoma sąsiadkami wyjątkowo się przyjaźniła i ceniła sobie tę długoletnią, sprawdzoną sąsiedzką zażyłość. Aktualnie w miejscu kamienicy zamieszkiwanej przez narratorkę znajduje się parking, chodnik, a obok przebiega ścieżka rowerowa (fot. 8).

\section{WYWIAD 5 (2.10.2018)}

Nazywam się W., urodziłam się 30 lipca 1916 r. na Ukrainie, w małej miejscowości Konotop. Po zakończeniu wojny w 1945 r. wraz z przyjacielem podjęliśmy decyzję o wspólnym życiu i przyjeździe do Łodzi razem 
z naszymi dziećmi. Zamieszkaliśmy wspólnie przy ulicy Próchnika 52. To była trzypiętrowa kamienica, a my mieszkaliśmy na trzecim piętrze. Mieliśmy tam trzypokojowe mieszkanie z kuchnią i łazienką. Warunki, jak na tamte czasy, były bardzo dobre. Była w mieszkaniu bieżąca zimna woda i mieliśmy w łazience nawet piec węglowy, który ogrzewał wodę do kąpieli. W pokojach były piece kaflowe. W kuchni gotowało się na piecu opalanym węglem, potem, nie pamiętam w którym roku, ale założyli gaz i gotowało się już na piecu gazowym. Byłam bardzo z tego zadowolona, bo już tak się nie brudziło mieszkanie od węgla i nie trzeba go już było wnosić na to trzecie piętro.

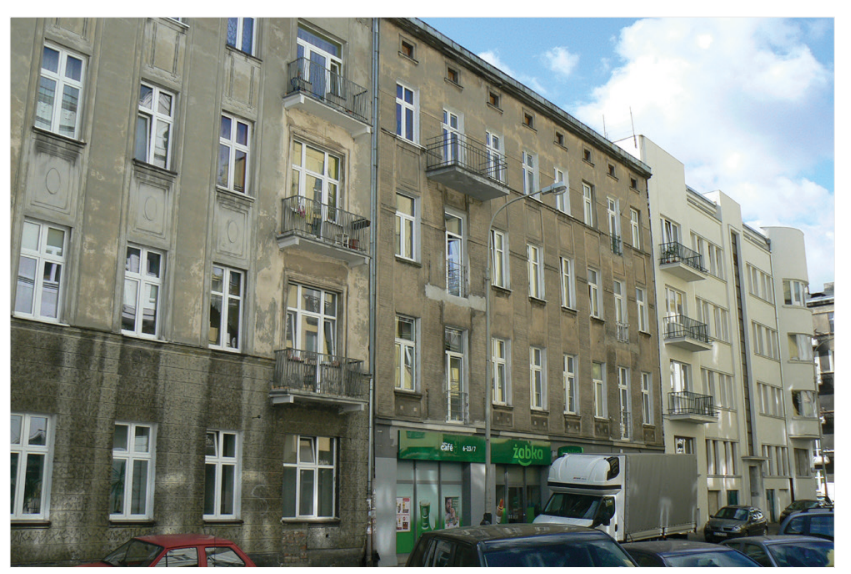

Fotografia 9. Ulica Próchnika 52 Źródło: M. Rejter (2019)

Lata młodości narratorki, które spędziła w Łodzi, przypadają na czas po II wojnie światowej, kiedy to w 1945 r. przyjechała do Łodzi wraz ze swoimi dziećmi z pierwszego małżeństwa oraz z drugim mężem, dla którego Łódź była miejscem urodzin, i jego dziećmi z pierwszego małżeństwa. Zamieszkiwała wraz ze swoją rodziną mieszkanie w kamienicy na ulicy Próchnika 52 (fot. 9). Warunki mieszkaniowe, jakie tam miała, uważała za bardzo dobre - była z nich zadowolona i wspomina je bardzo pozytywnie. Na początku swojego życia w Łodzi narratorka poświęciła się wychowywaniu dzieci, a dopiero kiedy były one większe, podjęła pracę zawodową.

\section{WYWIAD 6 (5.08.2018)}

Nazywam się I., urodziłam się w Łodzi 29 września 1945 r. Moja rodzina od pokoleń związana jest z Łodzią. [...] w wieku pięciu lat, czyli w 1950 r., wraz z rodziną przeprowadziłam się na ulicę Cieszkowskiego 9. Po prostu rodzice mając $\mathrm{w}$ pamięci sytuację przedwojenna, kiedy czynsze w mieszkaniu były bardzo drogie, i jeżeli pewnego miesiąca nie mogliby zapłacić za czynsz groziła im natychmiastowa eksmisja, wybudowali dom na działce, która była własnością rodziców mojego taty. I w 1950 r. wraz z rodzicami przeprowadziłam się na ulicę Cieszkowskiego 9, to była chyba wiosna, wczesna wiosna, a jesienią wprowadzili się również dziadkowie ze strony mojej mamy, czyli dziadek z babcią wprowadzili się również do nas. Pamiętam, że dom otaczał ogród, o który bardzo dbał mój tato. Były tam drzewa owocowe, kwiaty. Potem już, jak tato poszedł na emeryturę, to go uprawiał, mieliśmy pomidory. I w tym również domu, ten dom składał się z dwóch części, i po jednej stronie korytarza mieszkaliśmy my, to były dwa pokoje z kuchnia, a po drugiej stronie mieszkała moja babcia ze strony taty z synem, który był kawalerem.

Czas dzieciństwa narratorki przypada na drugą połowę lat 40. i lata 50. XX w. Z sentymentem wspomina ona okres swojego dzieciństwa, które spędziła w wybudowanym przez ojca domu przy ulicy Cieszkowskiego 9 (fot. 10). Pamięta, że jadła wyhodowane przez ojca warzywa i owoce. Wspomina także ogród pełen kwiatów. Ważnym wspomnieniem dla narratorki jest również to, że w domu mieszkała cała trzypokoleniowa rodzina, a dalsi krewni często z przyjemnością ich odwiedzali i byli zawsze mile widziani. Narratorka wspomina, że jej dom był zawsze otwarty i przyjazny dla gości, toteż chętnie przez nich odwiedzany. Pamiątką tego

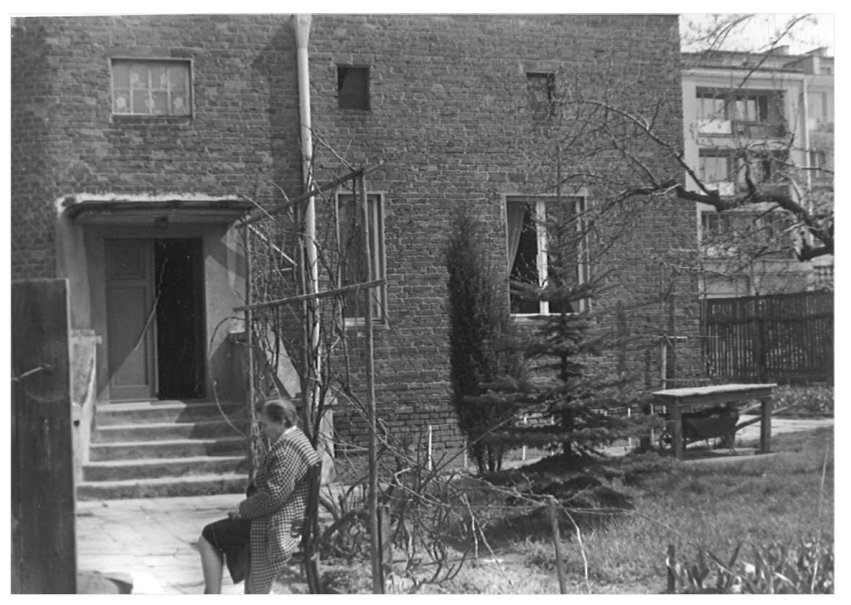

Fotografia 10. Ulica Cieszkowskiego 9 (1950) Źródło: archiwum narratorki

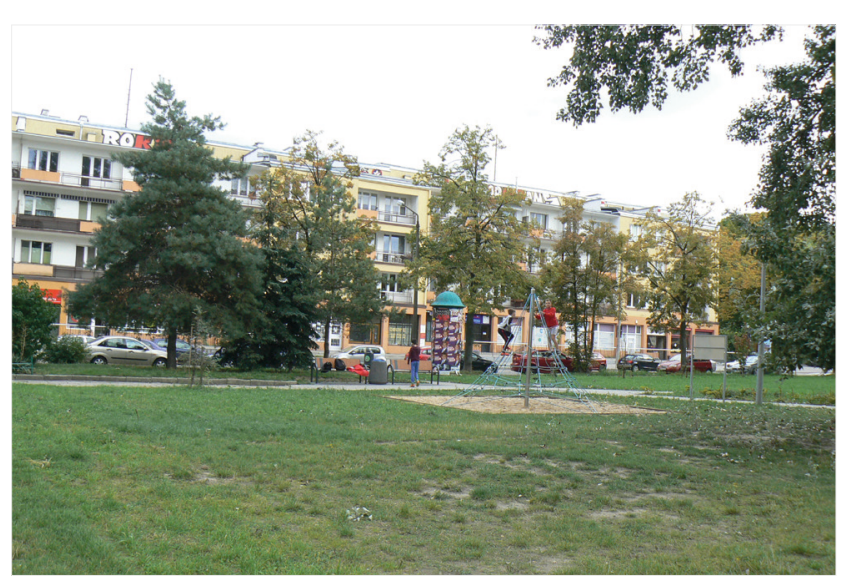

Fotografia 11. Ulica Cieszkowskiego 9 Źródło: M. Rejter (2020) 
jest uwieczniona na fotografii (z archiwum domowego narratorki) ciocia H., która była częstym gościem $\mathrm{w}$ tym domu. Obecnie w miejscu rodzinnego domu jest jedynie trawnik, widoczny na pierwszym planie (fot. 11). Natomiast na obu fotografiach widzimy na drugim planie długi blok o funkcjach mieszanych - mieszkaniowo-handlowych.

\section{WYWIAD 7 (31.01.2020)}

Urodziłem się pod Pabianicami, w leśniczówceu dziadka, 21 kwietnia 1942 r. Po wojnie w 1945 r. przyjechaliśmy do Łodzi i zamieszkaliśmy przy ulicy Piotrkowskiej 142. W bardzo ładnym mieszkaniu po właścicielu albo dyrektorze takiej fabryki, obok przy ulicy Roosevelta. Przędzalnie takie były duże. No i tam mieszkałem do chwili, kiedy się ożeniłem w wieku 26 lat. [...] Warunki były bardzo dobre, były trzy pokoje, kuchnia, łazienka, z tym, że piece kaflowe były. [...] Mieszkanie było bardzo dobre, piwnica jeszcze była, komórka była w podwórku. Towarzystwo było różne. Ja bardzo lubiłem to swoje mieszkanie. To najbardziej kultowe moje mieszkanie do tej pory. Z balkonem na ulicę Piotrkowska, także jak były jakieś pochody, to pełno gości do nas przychodziło, żeby oglądać 1 majowe demonstracje. W ogóle mieszkając na Piotrkowskiej, to było takie miejsce, że jak ktoś przychodził w Łodzi, coś chciał sobie kupić, to do Śródmieścia, i potem się mówiło, że na sikanie się do nas wchodziło i zawsze byli goście w domu. [...] Mieszkanie było naprawdę bardzo ładne, bardzo ładna klatka schodowa. Można powiedzieć, że na tamte czasy luksusowa. Gaz był, elektryczność oczywiście, z tym, że w łazience był taki piec, w którym się paliło. Kaflowe piece $\mathrm{w}$ pokojach. Duże mieszkanie, ponad $100 \mathrm{~m}^{2}$. Trzy okna na Piotrkowska, trzy okna od podwórka, duże ładne mieszkanie. No i jak się otworzyło, to był szum tej przędzalni obok. Ale to nie przeszkadzało.

Czas dzieciństwa narratora przypada na lata 40. XX w. Narrator w wieku 3 lat przyjechał wraz z rodziną do Łodzi, gdzie kolejne 23 lata swojego życia mieszkał

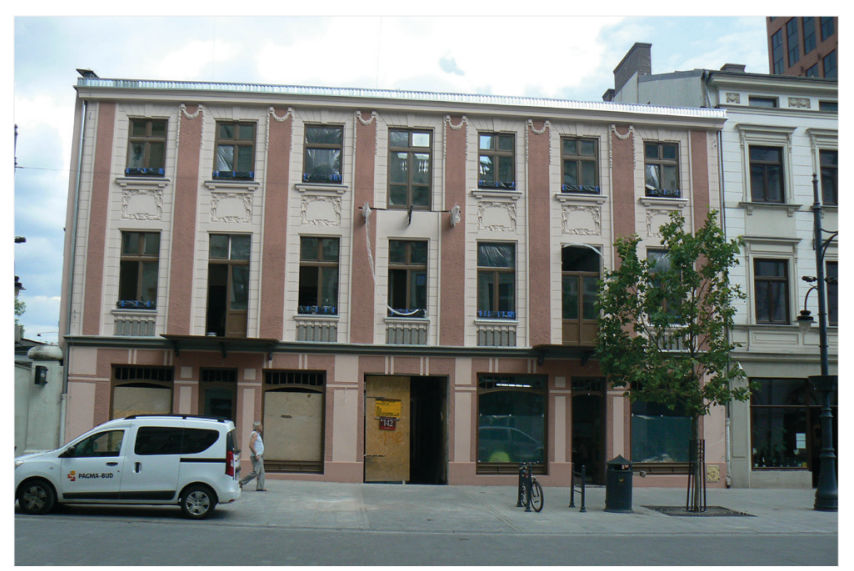

Fotografia 12. Ulica Piotrkowska 142 Źródło: M. Rejter (2020) w kamienicy na ulicy Piotrkowskiej 142 (fot. 12). Wspomina warunki mieszkaniowe jako bardzo dobre. Ciekawym społecznym aspektem jest w tej biografii to, że wtedy rodzina i znajomi odwiedzali się często przy różnych okazjach, czy to chęci zrobienia zakupów czy wspólnego oglądania pochodów z balkonu mieszkania. Zamieszkiwanie przy ulicy Piotrkowskiej traktowane było jako przywilej, dawało mieszkańcom renomę i stawiało ich wyżej w hierarchii społecznej.

\section{WYWIAD 8 (3.02.2020)}

Urodziłem się w 1936 r., 5 stycznia w Łodzi na ulicy Antoniewskiej 13, w dzielnicy Widzew, tak zwany Grembach to był. I tam mieszkali rodzice moi, ponieważ nie mieli swojego mieszkania. I tam właśnie wynajęty był taki pokój w domku jednorodzinnym. To była zima, styczeń, więc kilka dni po urodzeniu rodzice ze mną przenieśli się do mojej babci ze strony mojej matki i tam żeśmy zamieszkali. To było na ulicy, wtedy to się nazywała Pograniczna 46, a teraz nazywa się Czechosłowacka. No i tam mieszkaliśmy w pokoju z kuchnią. To były tak zwane baraki nazwane, które były budowane dla pracowników. Przed wojną tam była niemiecka fabryka, która zatrudniała pracowników i dla tych pracowników te baraki były tam zrobione. I w takim baraku tam dziadkowie mieli mieszkanie i tam się wprowadziliśmy i mieszkaliśmy tam przez całą okupację. Te baraki są w dalszym ciągu i ludzie tam mieszkają tak jak mieszkali podczas okupacji przed wojną z tym, że w tej chwili jest tam doprowadzona do mieszkań woda, kanalizacja itd. No, a przed wojną tego nie było, trza było chodzić do ubikacji. Ale było lepiej niż na Antoniewskiej, bo było cieplej, ale było ciaśniej, bo młodsi z dziadkami w jednym pomieszczeniu, ale było cieplej. No i tam się wychowywałem wraz z rodzicami przez okres przedwojenny od 1936 r. do 1939 r. I od 1939 r. jak się wojna zaczęła, całą okupację niemiecką do $1945 \mathrm{r}$. No, miałem tam kolegów. Mieszkali tam Niemcy i Polacy. Pamiętam kolegę najbliższego w tym czasie, Niemca z pochodzenia, nazywał się O. M. Potem od czasu wyzwolenia nie widziałem go i do dzisiaj nie wiem co się z nim dzieje.

Okres dzieciństwa narratora przypada na lata 40. i 50. XX w. Urodził się on przy ulicy Antoniewskiej13 (fot. 13), na tak zwanym Grembachu - osiedlu robotniczym, które powstało pod koniec XIX w. w podłódzkiej wsi Widzew. Życie na Grembachu związane było przede wszystkim z wybudowaną tu Fabryką Nici, która dawała pracę, mieszkania w przyfabrycznych domach i organizowała robotnikom czas po pracy. Jednakże krótko po narodzinach narratora jego rodzice wraz z nim przenieśli się do mieszkającej nieopodal babci, na ulicę Pograniczną 46 - obecnie to ulica Czechosłowacka (fot. 14). Przeprowadzka wynikała z chęci poprawy warunków mieszkaniowych, tak aby były lepsze dla nowo narodzonego dziecka. $\mathrm{W}$ domu babci narrator mieszkał 


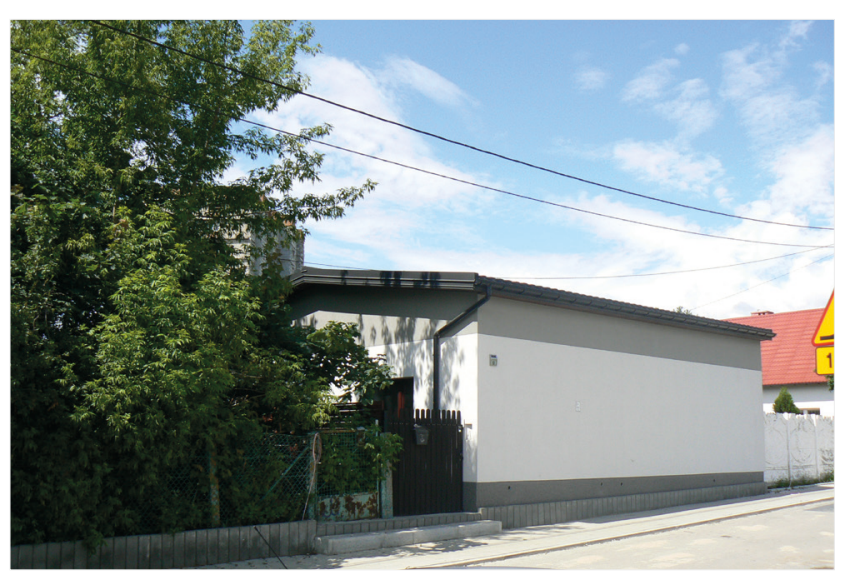

Fotografia 13. Ulica Antoniewska 13 Źródło: M. Rejter (2020)

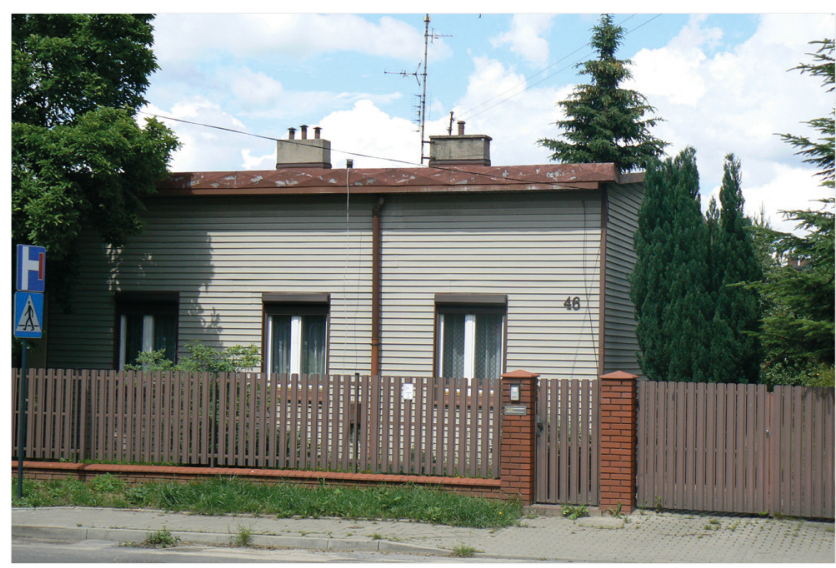

Fotografia 14. Ulica Czechosłowacka 46 Źródło: M. Rejter (2020)

przez dziewięć lat, tam nawiązał swoje pierwsze przyjaźnie, które z sentymentem wspomina do dziś dnia. Warto podkreślić, że dla narratora całkiem naturalne było, że obok siebie w przyjaźni zamieszkiwali ludzie różnych narodowości.

Warto w tym miejscu przywołać słowa innego łodzianina, Armina Richarda Hornbergera, który tak opisuje wielonarodowościową Łódź, w swojej książce Moja tódzka młodość:

W mieście wykształciła się specyficzna mieszanka ludności. Niemcy, Polacy, Rosjanie i Żydzi mieszkali w Łodzi obok siebie, a wielu z nich utrzymywało dobre kontakty. Naszymi sąsiadami z lewej strony byli Polacy, zaś na działce po prawej stronie mieszkali Żydzi. Mieliśmy z nimi dobre relacje. Spotykając się na ulicy grzecznie się sobie odkłanialiśmy. Świętowaliśmy wspólnie wesela, gdy umarł ktoś z naszego sąsiedztwa chodziliśmy razem na pogrzeby (Hornberger, 2011, s. 14).

Armin Richard Hornberger w latach 1930-1939 mieszkał w drewnianym domu przy ulicy Srebrzyńskiej 47. Jednak ten stan rzeczy, tak naturalny, który miał miejsce w Łodzi czterech kultur, od 1939 r. zaczął ulegać zmianie. Hornberger, podobnie jak i inni łodzianie narodowości niemieckiej, z chwilą wybuchu II wojny światowej wyjechał do rodziny do Niemiec.

\section{WYWIAD 9 (5.12.2019)}

Nazywam się M.., urodziłem się w 1950 r. i pierwsze 29 lat swojego życia mieszkałem $\mathrm{w}$ domu na ulicy Mostowej 19c, później Zelwerowicza 19c. [...] To był dom z dość dużym ogrodem, którego większą cześć uprawiała i zabiegała o nią moja mama i mój tata. [...] Mieszkałem tam, ciesząc się dużą swobodą ponieważ spędzaliśmy bardzo dużo czasu poza domem. Czyli szkoła, dom, okolice i sąsiedzi - to było najważniejsze, to co człowieka trzymało. Edukację jednak zacząłem od znanego wszystkim w sąsiedztwie przedszkola, które funkcjonuje do dzisiaj na ul. Małachowskiego. [...] Natomiast jak my spędzaliśmy czas na naszym osiedlu, bo to jest ważne. Co myśmy robili? Mianowicie, dzisiaj dzieci trzeba namawiać, żeby wyszły na ulice, nas trzeba było ściągać do domu. [...] Kolonia była o tyle charakterystyczna, że otoczona, zamknięty teren. Domki od ulicy Mostowej i Tkackiej i w środku ulica Okrężna. Więc myśmy się zwoływali i bawiliśmy się, a to graliśmy w piłkę, a to bawiliśmy się w jakieś podchody, a to jeździliśmy na rowerze urządzając wyścigi dookoła kolonii, prawda, na czas. Ponieważ nie mieliśmy zegarków, więc się liczyło jeden, dwa, trzy, cztery... i w ten sposób ustalało się czas przejazdu kolejnego zawodnika ścigającego się na rowerze. Robiliśmy wyprawy na rowerach, głównie w kierunku Stoków i pola na Radiostacji. A więc to były nasze zajęcia: wycieczki rowerowe na Stoki, do tzw. Kotliny Słonia, to ciekawe miejsce. Mianowicie na Stokach była kopalnia piasku. Była to olbrzymia góra piachu, ściana piachu, po której się wspinaliśmy. [...] A nazywała się Kotliną Słonia, ponieważ na górze tej góry piachu, tego wykopu, były jakieś resztki nie wiem cmentarza, płyt nagrobnych i jedna z nich była jakby w kształcie, nie wiem, czy macewa czy płyta nagrobna w kształcie słonia. Po prostu taka potłuczona na kawałki, ale ten słoń górujący nad tą kotliną i myśmy mówili, jeździmy do Kotliny Słonia. A na kolonii bawiliśmy się, głównie grając w kometkę i różnego rodzaju podchody. [...] To były lata szkoły podstawowej. Myśmy tam na sanki chodzili do parku 3 Maja przy ul. Małachowskiego, jest górka wysokości może $3 \mathrm{~m}$ góra, a nam się wydawało, że to duża góra, i z tej góry zjeżdżaliśmy na sankach. No duża góra, na którą chodziło się na sanki, była w parku Staszica na Narutowicza przy Wierzbowej. No i druga w parku Staszica, gdzie się jeździło prosto na sankach, a w bok na tzw. "giga", czyli na butach po lodzie. A więc nasze zabawy to jazda na rowerze, to gra w kometkę, to zabawa $\mathrm{w}$ podchody, granie $\mathrm{w}$ piłkę, w chowanego i również różnego rodzaju zabawy w ogrodzie.

Narrator urodził się w domu przy ulicy Zelwerowicza 19ci tam mieszkał przez 29 lat swojego życia (fot. 15). Czasy jego dzieciństwa przypadają na lata 50. XX w. $Z$ sentymentem wspomina dom i ogród oraz codzienne 


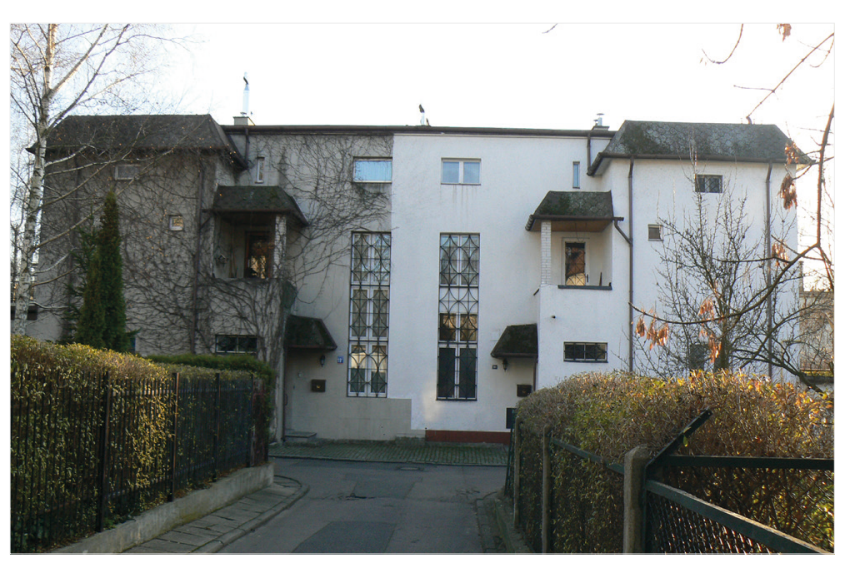

Fotografia 15. Ulica Zelwerowicza 19c Źródło: M. Rejter (2019)

życie chłopaków z osiedla, na które składały się wyprawy rowerowe, zabawy, gry, wspólne spędzanie czasu z kolegami i wymyślanie przeróżnych rozrywek. Jest to bardzo ciekawy obraz ówczesnego życia młodego pokolenia, dlatego też tak długi fragment biografii został zaprezentowany. Współcześnie dzieci całkowicie inaczej spędzają czas, warto więc wspominać, jak bywało dawniej.

\section{WNIOSKI}

Przedstawione wywiady pokazały, że każdy człowiek nie tylko zapisuje przestrzeń, odczytuje to, co w niej zostało napisane, ale również naznacza ją swoim działaniem i obecnością, nawiązując z nią bliskie relacje, współtworząc "uczłowieczoną przestrzeń", zaczynając od najbliższego sobie miejsca, np. podwórka do zabaw i relacji z innymi jej użytkownikami, po wspólne miejsca większych zbiorowości (Jałowiecki, 2012). Koncepcja miejsca według Jałowieckiego zakłada, że miejsce wytwarzane jest przez społeczność w długim procesie adaptacji człowieka i środowiska. Miejsce jest doskonale znane, przyswojone, własne, ograniczone, ma charakter zmysłowy, można je zobaczyć, poczuć, usłyszeć (Jałowiecki, 2012). Dlatego też tak istotne są przedstawione miejsca zamieszkania, wokoło których toczyło się życie narratorów i opisane sposoby spędzania czasu. Mimo tego, że społeczeństwo jawi się jako sfera obiektywnych faktów, to w istocie tworzą je subiektywne znaczenia (Berger, Luckmann, 2010). W koncepcjach, w których rozumiane są wartości społeczne, stawia się w centrum uwagi życie społeczne, a w szczególności znaczenia działań ludzkich i przekazów komunikacyjnych, jakie ludzie wymieniają między sobą. Paradygmat konstrukcjonistyczno-narracyjny zakłada wielowersyjność świata, a także konsensualny, kulturowy charakter wiedzy nabywanej i przekazywanej przez jednostki. W tym ujęciu podstawowe miejsce zajmuje proces nadawania znaczeń, a rzeczywistość jest nie tylko doświadczana za pomocą języka, ale i przez język jest konstruowana. Oznacza to, że umysł ludzki ujmuje rzeczywistość w formę opisów, narracji, interpretuje dziejące się zdarzenia jako określone historie, opowieści, a doświadczenia osobiste porządkuje w postaci narracji posiadających własny sens. Od owej narracji, a w szczególności od ramy narracyjnej, zależy to, jak jednostka doświadcza siebie i otaczający świat oraz które aspekty rzeczywistości zostaną dostrzeżone, nazwane i wyrażone. W związku z tym narracja, jako metoda opisu rzeczywistości, sposobu komunikacji, wyrażania i ekspresji jednostki, stała się głównym wątkiem postępowania badawczego $\mathrm{w}$ tym artykule.

\section{PODSUMOWANIE}

Narracja o doświadczeniach biograficznych odkrywa to, co wydarzyło się w przestrzeni społecznej z punktu widzenia uczestniczących i działających w niej jednostek (Kaźmierska, Waniek, 2020). Przedstawione $\mathrm{w}$ artykule biografie pozwalają na uwzględnienie różnorodnych zdarzeń przeżytych i opisanych przez jej bohaterów. Opowiedziane historie składają się na intrygujący obraz Łodzi w jej pierwszych powojennych dekadach. Zobrazowano różne aspekty życia społecznego w przestrzeni miasta. Począwszy od zamieszkiwania w prostych drewnianych domach, po mieszkanie w kamienicach w komfortowych, jak na tamte czasy, warunkach. Narratorzy wspominali również o aktywnościach i zabawach dzieci i młodzieży w tamtych latach. Przedstawione w biografiach sytuacje przez lata zostały przefiltrowane i w pamięci pozostało to, co najważniejsze - to co sprawiało najwięcej radości lub bolało. Emocje tworzą filtr, który pozwala na uwypuklenie pewnych istotnych zdarzeń, a zatarcie tych mniej ważnych dla młodej osoby. Każdy człowiek i miejsce mają własne charakterystyczne dla siebie cechy, wyróżniające je wśród innych. Przede wszystkim zarówno ludzie, jak i miejsca są dla kogoś ważne. Dzięki udostępnionym narracjom czytelnik ma wyjątkową możliwość znalezienia się choć na chwilę w miejscach oraz czasach ważnych dla narratorów i spojrzenia na miasto oczyma młodych mieszkańców powojennej Łodzi.

Każde miasto ma swój własny, specyficzny obraz będący rezultatem nakładania się po wielokroć indywidualnych obrazów. Toteż istnieje wiele społecznych obrazów podzielanych przez sporą liczbę mieszkańców. Jednak każde indywidualne ujęcie jest niepowtarzalne, zawierające specyficzne elementy, które nie są podzielane przez ogół, mimo tego są częścią obrazu społecznego (Lynch, 2011). Doświadczenia wyrażane w biografiach wyprowadzają nas poza wewnętrzne 
życie jednostki i stają się źródłem poznania ponadindywidualnego społecznego świata. Świadome życie jednostki jest w znacznej mierze wytworem działań środowiska społecznego, w którym jednostka wyrosła. Przejawia się to fragmentarycznie $\mathrm{w}$ całokształcie indywidualnych doświadczeń. Jednak to sama jednostka, poprzez swoje postawy wartościujące i działania czynne, staje się wraz z innymi współtwórcą rzeczywistości społecznej, biorąc udział w jej przekształcaniu. Rzeczywistość społeczna jest częściowo uporządkowaną syntezą wielu żyć osobistych, a każda indywidualna postawa jest realną siłą społeczną. Mając różnorodne biografie ze zbiorowości ludzkiej, możemy odtworzyć systemy i wzory, które w niej istniały i te zmiany, które w niej zaszły (Chałasiński, 1976). Zatem artykuł ten miał za zadanie pokazanie we fragmentach mikroświata społecznego życia i zachowania młodego pokolenia powojennego.

\section{BIBLIOGRAFIA}

Apanowicz, J. (2002). Metodologia ogólna. Gdynia: Wydawnictwo "BERNARDINUM".

Baedeker łódzki (2015). Pobrane z: http://baedekerlodz. blogspot.com/2015/08/kino-roma-przy-ulicy-rzgowskiej.html (20.06.2020).

Berger, P.L., Luckmann, T. (2010). Społeczne tworzenie rzeczywistości: traktat z socjologii wiedzy. Warszawa: Wydawnictwo Naukowe PWN.

Castells, M. (1982). Kwestia miejska. Warszawa: Państwowe Wydawnictwo Naukowe.

Chałasiński, J. (1976). Polonia amerykańska. W: W.I. Thomas, F. Znaniecki, Chtop polski w Europie i Ameryce. T. I (s. 7-29). Warszawa: Ludowa Spółdzielnia Wydawnicza.

Czechowicz, M. (2015). Baedeker łódzki. Pobrane z: http://baedekerlodz.blogspot.com/2015/08/kino-roma-przy-ulicy-rzgowskiej. html (20.06.2020).

Darmach, K. (2020). Zapisywanie świata. W poszukiwaniu antropografii. Łódź: Wydawnictwo Uniwersytetu Łódzkiego.

Dzieciuchowicz, J. (1974). Rozwój budownictwa w Łodzi 1945-1965. Zeszyty Naukowe Uniwersytetu Eódzkiego. Nauki Matematyczno-Przyrodnicze, 55, 31-46.
Hornberger, A.R. (2011). Moja tódzka młodość. Łódź: Wydawnictwo WIST.

Jałowiecki, B. (2012). Czytanie przestrzeni. Kraków-RzeszówZamość: Konsorcjum Akademickie.

Kaczmarek, J. (2001). Miejsce - w poszukiwaniu właściwej miary. W: H. Rogacki (red.), Koncepcje teoretyczne i metody badań geografii społeczno-ekonomicznej i gospodarki przestrzennej (s. 73-81). Poznań: Bogucki Wydawnictwo Naukowe.

Kaczmarek, J., Liszewski, S. (1991). Ruchliwość przestrzenna mieszkańców Łodzi w świetle analizy zmian miejsc zamieszkania. Acta Universitatis Lodziensis. Folia Geographica, 13, 41-55.

Kaczmarek, S. (1996). Struktura przestrzenna warunków zamieszkania w Łodzi. Łódź: Łódzkie Towarzystwo Naukowe.

Kaźmierska, K., Waniek, K. (2020). Autobiograficzny wywiad narracyjny. Metoda - technika - analiza. Łódź: Wydawnictwo Uniwersytetu Łódzkiego.

Kwiatek, J., Lijewski, T. (1998). Leksykon miast polskich. Warszawa: Muza S.A.

Lesiakowski, K. (2019). Gomułkowska rzeczywistość. Łódź w latach 1956-1970. Łódź: Wydawnictwo Uniwersytetu Łódzkiego.

Lynch, K. (2011). Obraz miasta. Kraków: Wydawnictwo Archiwolta.

Majer, A. (2015). Mikropolis. Socjologia miasta osobistego. Łódź: Wydawnictwo Uniwersytetu Łódzkiego. https://doi. org/10.18778/7969-856-1

Miszewska, B. (2014). Szlakiem znaków i symboli dawnego Wrocławia. W: M. Madurowicz (red.), Kształtowanie wspótczesnej przestrzeni miejskiej (s. 192-202). Warszawa: Wydawnictwa Uniwersytetu Warszawskiego.

Nykiel, K. (2020). Łódzkie drewniaki - wyburzyć! Pobrane z: http://miejmiejsce.com/miasto/lodzkie-drewniaki-wyburzyc (17.06.2020).

Szafrańska, E. (2016). Wielkie osiedla mieszkaniowe w mieście postsocjalistycznym. Geneza, rozwój, percepcja. Łódź: Wydawnictwo Uniwersytetu Łódzkiego.

Zieliński, M. (2014). Człowiek jako twórca, użytkownik oraz element krajobrazu miejskiego. W: M. Madurowicz (red.), Kształtowanie współczesnej przestrzeni miejskiej (s. 179-191). Warszawa: Wydawnictwa Uniwersytetu Warszawskiego.

Żyłko, B. (2000). Wstęp tłumacza. Miasto jako przedmiot badań semiotyki kultury. W: W. Toporow, Miasto i mit (s. 5-30). Gdańsk: Wydawnictwo Słowo/obraz terytoria.

Artykuł wpłyną: 5 lipca 2020

Zaakceptowano do druku: 5 listopada 2020 